DOI: 10.17951/lrp.2020.40.1.41-53

\author{
JANUSz Miąso \\ Uniwersytet Rzeszowski \\ ORCID - 0000-0002-2055-0152
}

\title{
PROMOCJA I INTENSYFIKACJA KOMUNIKACJI INTERPERSONALNEJ BEZPOŚREDNIEJ RODZIC - DZIECKO, NAUCZYCIEL - UCZEŃ W ŚWIECIE TECHNOKRACJI I OSACZANIA KAPITAŁEM MATERIALNYM
}

Nie ma edukacji bez relacji...

\begin{abstract}
Streszczenie: Wprowadzenie: Reizacja człowieka (łac. res - rzecz), szczególnie dziecka, czyli osaczanie na ogromną skalę światem materialnym, w tym szczególnie gadżetami medialnymi, to aktualnie jeden $z$ największych problemów psychologicznych i pedagogicznych i zarazem jedno z największych wyzwań. Świat rzeczy, w tym świat multimediów, to także piękny świat, który bardzo pomaga w codziennym życiu, szczególnie w kontekście pandemii, ale równocześnie wszystko to wymaga wielkiej mądrości, aby nie zniszczyć bezcennych relacji międzyludzkich, interpersonalnych - międzyosobowych, bezpośrednich, face to face, bliskości, które są szczególnie ważne i bezcenne dla prawidłowego rozwoju dziecka i każdego człowieka. Cel badań: Celem niniejszych badań jest zwrócenie uwagi na powyższy problem i szczególna mobilizacja do promowania i wzmacniania ważnych i bezwzględnie koniecznych relacji interpersonalnych bezpośrednich, których zauważa się poważny deficyt. W tej kwestii wydaje się, że badania są ciągle konieczne. Wielu nauczycieli w trakcie moich rozmów z nimi i wywiadów potwierdza potężny deficyt wiedzy o komunikacji interpersonalnej wśród rodziców, a także trudność z jej asymilacją w życiu codziennym, m.in. z powodu tempa życia i przeniesienia komunikacji w komunikację zapośredniczoną medialnie. Promowanie i permanentny trening komunikacji interpersonalnej od najmłodszych lat przez rodziców i nauczycieli z dziećmi i uczniami, a także między sobą to nadzieja na uratowanie esencji człowieczeństwa i społeczeństwa.
\end{abstract}

Słowa klucze: dziecko, kapitał materialny, komunikacja interpersonalna, rodzic, technokracja 


\section{WPROWADZENIE}

Wiele osób, szczególnie nauczycieli, studentów - przyszłych nauczycieli, zdroworozsądkowo myślących ludzi zwraca dziś uwagę na potężny problem, na swoistego rodzaju osaczenie małego dziecka nadmiarem zabawek, rzeczy materialnych, a następnie technokratycznymi gadżetami, takimi jak małe laptopy do oglądania bajek, komórki dostępne już od najmłodszych lat. Równocześnie zauważamy dosyć często swoistego rodzaju zagubienie małego człowieka w nadmiarze materii. Wiele osób stwierdza, że czasem nie wie, co kupić dziecku, które już wszystko ma. Nazywam ten proces reizacją osobowości, człowieka - od łacińskiego słowa res - rzecz. Nauczyciele w prowadzonych przeze mnie wywiadach zwracają uwage na silną potrzebę bliskości młodego człowieka, dziś deficytową - „proszę Panią mogę się przytulić” - mówi nastolatka do swojej pedagog, „bo tak bardzo mi tego brakuje..."; jedna z mam opowiadała, że córka przybiega do jej łóżka i tuląc się jak małe dziecko, prosi: „Mamo przytul mnie, bo tak bardzo potrzebuję twojej miłości...". To autentyczne wydarzenia, które opowiedzieli mi moi rozmówcy. Przykłady te można mnożyć. Antropologia akcentuje pewne trwałe i niezmienne potrzeby ludzkie, niezależnie od czasu i ogromu zmian. Aktualnie do niezwykle deficytowych ludzkich potrzeb należy potrzeba realnej bliskości. Coraz częściej bowiem przeżywamy „wirtualną bliskość” i realną samotność, co dotyczy także najmłodszych i to dla nich może być szczególnie dramatyczne, teraz i w przyszłości. Dlatego wzmacnianie i intensyfikacja komunikacji interpersonalnej, a więc między OSOBAMI, bezpośredniej - face to face, gdzie bliskość jest bezcenną wartością, okazuje się absolutną koniecznością chwili, aby ratować nasze człowieczeństwo i bardziej ludzkie społeczeństwo (zob. Szmyd, 2015). Jest to główny problem badawczy niniejszego przedłożenia, wymagający ciągłych badań, analiz i asymilacji.

\section{TECHNOKRACJA W ŻYCIU DZIECI I MŁODZIEŻY}

Profesor Maciej Tanaś, pedagog medialny, ekspert w kwestii oddziaływania mediów, stwierdza znamiennie, że świat mediów pozostawia głęboki ślad w umyśle dziecka. Współczesna generacja wyrasta w środowisku mediów w przeciwieństwie do pokoleń minionych. Ten ślad jest trwały, media bowiem nie tylko przekazują informacje, lecz także i wywołują emocje, kształtują sferę wyobraźni, budzą pragnienia i marzenia, mieszają hierarchię wartości i realizują zadania niekiedy zbieżne z oczekiwaniami pedagogów i nauczycieli (Tanaś, 2007, s. 198).

Dalej profesor Tanaś, w rozdziale o wychowaniu i mediach, analizuje znamiennie i wnikliwie, podkreślając, że półśrodki, działania improwizowane, cha- 
otyczne odruchy przynoszą zatrważające skutki, takie jak: zaburzenie poczucia tożsamości, sprzeczność celów i treści wychowawczych, zagubienie informacyjne, brak rozumienia rzeczywistości, zastępowanie naturalnych relacji międzyludzkich bliskością bohaterów TV. Zatrważająca krótkowzroczność, brak myśli i wizji skazują nas na chroniczne nieprzygotowanie, na jałowe deptanie w miejscu, na niemożność przekazania spójnej wiedzy o świecie przyszłym pokoleniom i na tragiczne niespodzianki. Hegemonia chwilowego zysku i nieumiejętność przewidywania skutków pomieszania rzeczywistości realnej i medialnej powoduje niespójną, nieciągłą wizję świata, przynosząc w efekcie chaos etyczny, światopoglądowy i zaburzenia osobowości. Melanż informacyjno-propagandowy w mediach nie tyle bawi, ile przede wszystkim uniemożliwia prawidłową samoocenę, utrudnia odbiorcy znalezienie właściwego miejsca w rzeczywistości, przez szybkość przekazu, pozbawiając go czasu potrzebnego na refleksję i działanie. Migający ekran przed drzemiącymi widzami jest znamieniem czasu. Także utrata punktów odniesienia i erozja zasad (Tanaś, 2007, s. 199; zob. Patzlaff, 2008).

Bardzo znamiennie i krytycznie zarazem na temat technokracji pisze Neil Postman w głośnej książce Technopol, w której analizuje konsekwencje ostrego starcia kultury z techniką, zwraca także szczególną uwagę na erozję zasad. Według niego informacja stała się czymś w rodzaju śmieci, które nie tylko nie potrafią udzielić odpowiedzi na najbardziej podstawowe pytania człowieka, ale także są ledwie przydatne, gdy chcemy nadać spójny kierunek rozwiązaniu jakiegokolwiek doczesnego problemu. Mówiąc inaczej: technopol rozkwita w środowisku, w którym zerwaniu uległ związek między informacją a celem człowieka, to znaczy informacja pojawia się niezróżnicowana, do nikogo konkretnie niekierowana, w ogromnej objętości i z szaloną prędkością, oderwana od teorii, znaczenia i celu. Wszystko to, akcentuje Postman, stworzyło nowy świat, który nazywa „światem a kuku”, w którym raz to, raz inne zdarzenie pojawia się na chwilę w polu widzenia i znów znika. To świat nieprawdopodobny; świat, w którym baconowską ideę postępu ludzkości zastąpiła idea postępu technologicznego. Celem nie jest zmniejszenie ignorancji, zwalczanie przesądów i ujmowanie cierpienia, lecz dostosowanie się do wymagań nowych technologii. Oczywiście powtarzamy sobie, że takie dostosowanie doprowadzi do lepszego życia, ale to tylko retoryczna pozostałość ustępującej technokracji. Jesteśmy kulturą, która sama z siebie czyni strawę dla informacji i mało kto zastanawia się choćby nad tym, jak kontrolować ten proces. Działamy dalej z założeniem, że informacja jest naszą przyjaciółką; wierzymy, że kultury mogą dotkliwie cierpieć z powodu braku informacji - co też, rzecz jasna, jest prawdą. I dopiero teraz zaczynamy rozumieć, że kultury mogą również dotkliwie cierpieć z powodu zatoru informacyjnego, z powodu informacji bez znaczenia, informacji pozbawionej mechanizmów kontrolnych - znamiennie konstatuje profesor Postman 
(1995, s. 89-90) - informacji straszliwie niszczącej, która dziś w ogromnej skali hejtu jest w stanie doprowadzać do ogromnej skali destrukcji, szczególnie wśród dzieci i młodzieży, aż po tendencje suicydalne (zob. Spitzer, 2016).

Niezwykle trafnie i aktualnie kwestie ogromnej dynamiki kultury popularnej, zmediatyzowanej, wśród młodzieży podejmuje Zbyszko Melosik, który obszernie analizuje mody, trendy, a zarazem niebezpieczeństwa, którymi intensywnie żyje współczesna młodzież. Niestety nadmiar tego wszystkiego powoduje z jednej strony dynamikę życia i zwiększenie szans, ale z drugiej ogromną skalę bardzo złożonych i skomplikowanych destrukcji (zob. Tapscott, 2010). W tym miejscu pozwolę sobie zatrzymać się na chwilę na komunikacji online i Facebooku, która to przestrzeń niewątpliwie daje ogromne możliwości komunikacyjne, o czym pisze Melosik, ale równocześnie badania przeprowadzone wśród dzieci i młodzieży wykazują, że im większe poczucie samotności odczuwają oni w realnym życiu, tym większe jest ich zaangażowanie w komunikację online. Cykliczny obniżony nastrój, poczucie samotności, niskie poczucie własnej wartości oraz niepokój to kilka tendencji, które mogą pojawiać się pod wpływem nadmiaru komunikacji online, akcentuje profesor. Obecność na Facebooku może u części aktywnych tam osób kompensować brak wartościowych więzi w realnym życiu, stanowić antidotum na poczucie odrzucenia w niewirtualnej codzienności (Melosik, 2013, s. 246), w której tak wielu młodych brakuje bliskości.

Warto jeszcze na chwilę zatrzymać się przy tak ważnych kwestiach dla młodzieży, jakimi są przyjaźnie, korzystając z myśli i analiz Zbyszko Melosika, który pokazuje ten świat w przestrzeni realnej i wirtualnej. W realnym życiu nawiązywanie i potwierdzanie przyjaźni jest długim procesem, w którym relacje są konstruowane przez wydarzenia. Najistotniejszymi komponentami przyjaźni są lojalność i poleganie na sobie, weryfikowane podczas różnych trudnych, a niekiedy krytycznych sytuacji. Natomiast zastosowanie pojęcia przyjaźni w stosunku do większości nowych znajomych na Facebooku stanowi w tym kontekście formę strategii marketingowej, możemy co najwyżej mówić tu o zdawkowych wirtualnych znajomościach, a nie o głębszych relacjach. Profesor Melosik kontynuując te głębokie analizy, przytacza kilka mocnych stwierdzeń, potwierdzających powyższe tezy, które akcentują, że w świecie Facebooka nie trzeba wielkiego wysiłku, aby stać się „przyjacielem” innych użytkowników, a „przyjaźń” raz stworzona nie wymaga nawiązania głębszych relacji. Jest przy tym bardzo prawdopodobne, że im większa jest sieć przyjaciół na Facebooku, tym mniej czasu i wysiłku można zainwestować w każdą jednostkę. Występuje więc tam tendencja do zwiększania liczby przyjaciół bez zwiększania wysiłku, aby „przyjaźnie” pogłębiać. Badania wykazują także, że im więcej ktoś ma przyjaciół w tym portalu, w tym mniejszym stopniu oczekuje od nich wsparcia. W Sieci bowiem istnieją krótkotrwałe, lecz 
intensywne, zogniskowane, szybkie i przeciążone więzi społeczne, przy czym owe „słabe więzi” ulegają coraz większemu rozpowszechnieniu. Tak więc facebookowe relacje między ludźmi do pewnego stopnia przypominają, zdaniem profesora Melosika, relacje, jakie można zaobserwować w restauracjach McDonalds - są szybkie, powierzchowne i puste. Nie tworzą głębszych więzi, są od „punktu do punktu”, a między kolejnymi interakcjami „nic nie ma”, relacje są poddane anihilacji, po czym następują kolejne wznowienia. Facebook przyczynia się więc do swoistej makdonaldyzacji relacji międzyludzkich. Jednocześnie człowiek wchodzi w spiralę przymusu interakcji, w nawyk powierzchownych spotkań, które nie mają końca i są celem samym w sobie. Jak pisał Jean Baudrillard, którego przywołuje Zbyszko Melosik - dokonuje się przyjemne odurzenie elektroniczną interakcją, która działa jak narkotyk i w której można spędzić całe życie bez przerw. Ludzie bowiem zaczynają przedkładać spotkania na Facebooku nad spotkania w rzeczywistości, co powoduje, że ich związki z innymi stają się coraz bardziej powierzchowne. $Z$ kolei interakcje na Facebooku są wprost wyjałowione $\mathrm{z}$ wielu kluczowych dla relacji międzyludzkich zmysłowych komponentów, bezcennych dla troski o człowieczeństwo i jego głębię, w każdym okresie życia, szczególnie w okresie młodości (Melosik, 2013, s. 246-248).

\section{OSACZANIE ŚWIATEM MATERIALNYM WRAZ Z PERMANENTNĄ PRZEJŚCIOWOŚCIĄ}

Kenneth Gergen w mocnej książce Nasycone Ja, gdzie wnikliwie i zarazem prawdziwie analizuje potężną skalę nasycenia, a nawet przesycenia współczesnego człowieka informacją, technokracją, nadmiarem relacji i spraw, a także szalonym tempem życia. Pisze także, że w nowym wydaniu książki był nieprzygotowany na alternatywną nową eksplozję, do jakiej doszło w kulturze - oto ludzie nie stapiają się z ludźmi, lecz z tym, co materialne. W minionym stuleciu maszyna stała się przedmiotem powszechnego uwielbienia, $\mathrm{z}$ elektrycznością, napędem odrzutowym, energią atomową i mikroprocesorem, by podać tylko kilka przykładów, które zaczęła otaczać „zbawcza aura”. Wraz z rozwojem wynalazków, takich jak soczewki kontaktowe, aparaty słuchowe, sztuczne szczęki, implanty piersi i zegarki na rękę, został przygotowany grunt pod kategorialną zapaść. W każdym $\mathrm{z}$ tych przypadków technika jest wiązana $\mathrm{z}$ ludzkim ciałem $\mathrm{w}$ taki sposób, że odtwarza się lub wzmacnia ludzkie funkcje. Komputer ponadto dodał zupełnie nowy wymiar do tej kompresji człowieka i maszyny. Już nie od ludzkiego mózgu, ale od komputera oczekuje się przeprowadzenia złożonych rozumowych obliczeń; to dzięki komputerowi jesteśmy też w stanie przypomnieć sobie adresy, numery 
telefonów, poprawną pisownię i inne myśli z wcześniejszych lat. Rozumowanie i prawidłowe zapamiętywanie to dziś produkt uboczny techno-istoty. Tego rodzaju technologie, świat materialny coraz częściej wplatają się w nasze ciało. Szkła kontaktowe zastępują okulary, aparaty słuchowe wprowadza się głęboko w ucho, a stymulatory serca i dozujące insulinę urządzenia wszczepia pod skórę. Stoimy dziś przed potencjalnym przekształceniem wszystkich mikroprocesorów w materiały chemiczne, tysiąc razy mniejsze i szybsze niż mikroprocesor. W przyszłości w mózgu lub krwioobiegu będą umieszczane czujniki informacji, a nawet małe roboty. Działanie więc ludzi i maszyn staje się zatem funkcjonalnie ekwiwalentne. W konsekwencji zobaczymy ludzi i maszyny zamkniętych we wzajemnie podtrzymujących się systemach działania. I znów niepodobna będzie odróżnić ludzi od maszyn, znamiennie akcentuje Kenneth Gergen (2009, s. 22-23).

Alvin Toffler w swoich także znamiennych badaniach zaprezentowanych w książce Szok przyszłości podejmuje także trafnie wiele kwestii związanych między innymi z osaczaniem nadmiarem rzeczy materialnych, a także z równie ciekawym zagadnieniem permanentnej zmienności, przejściowości, krótkotrwałości rzeczy materialnych i ich związków z człowiekiem. W części pt. Przejściowość, w rozdziale Społeczeństwo wyrzucające rzeczy rozpoczyna od ekspansji lalki Barbie, jej ciągłych nowych modeli i konstatuje, że mała dziewczynka zmieniająca ciągle stary model na nowszy, otrzymuje poglądową lekcję na temat istoty nowego społeczeństwa, mianowicie tego, że kontakty ludzi z rzeczami stają się, przy ich bardzo dużej ilości, coraz bardziej przelotne. Ocean przedmiotów fizycznych wytworzonych przez ludzi jest umieszczony w bezmiarze tworów natury. Jednakże dla jednostki coraz ważniejsze staje się środowisko stwarzane przez technologię, akcentuje Toffler. Plastik i beton, mieniąca się barwami w świetle ulicznym karoseria samochodu, oszałamiający widok miasta z okien odrzutowca - oto rzeczywistość, w której przebiega życie człowieka. Przedmioty wytworzone przez ludzi wkraczają do świadomości człowieka i ubarwiają ją. Ich liczba - zarówno bezwzględna, jak i mierzona w stosunku do środowiska naturalnego - rośnie niezmiernie szybko. Rzeczy mają olbrzymie znaczenie, i to nie tyle ze względu na ich funkcjonalną użyteczność, ile na ich oddziaływanie psychologiczne. Utrzymujemy kontakty z rzeczami, rzeczy wpływają na nasze poczucie ciągłości lub braku ciągłości. Odgrywają rolę w strukturze sytuacji, skrócenie naszych kontaktów z rzeczami w efekcie przyspiesza tempo życia. Co więcej, nasz stosunek do rzeczy odzwierciedla głębsze wartości ludzkie. Trudno o bardziej dramatyczną różnicę niż ta, która dzieli nowe pokolenie dziewczynek, chętnie wymieniających swoje Barbie na ulepszony model, od ich matek lub babek, które były na stałe przywiązane i kochały jedną i tę samą lalkę, dopóki ta nie rozleciała się po prostu ze starości. Na tej różnicy zasadza się kontrast między przeszłością a przyszłością; między społeczeństwami opartymi 
na trwałości, a nowym, szybko powstającym społeczeństwem opierającym się na krótkotrwałości (Toffler, 1998, s. 59-60).

Toffler mocno akcentuje także niebezpieczeństwo „kultury wyrzucania”, mocno związanej z konsumpcją, która ma swoje istotne następstwa psychologiczne. Jako przykład podaje papierowe ubranka, szczególnie dla dzieci. Jak pisze, już niedługo dziewczynki będą mogły chlapać się lodami, rysować rysunki na swoich sukienkach i robić z nich wycinanki, podczas gdy ich matki będą się życzliwie uśmiechały, patrząc na tę twórczość. A dla dorosłych, którzy chcą dać upust swoim twórczym instynktom, są nawet komplety ubrań „pomaluj się sam” razem z pędzlami. Aby więc dostosować się do wyrzucanych produktów, rozwijamy mentalność wyrzucania. Mentalność ta z kolei stwarza - między innymi - zestaw wartości całkowicie zmienionych w odniesieniu do posiadania, zmniejszenie trwałości kontaktów ludzi z rzeczami. Zamiast przywiązania przez stosunkowo długi okres do jednego przedmiotu jesteśmy związani przez krótkie okresy z następującymi po sobie przedmiotami, które zajmują miejsce swych poprzedników i dotyka to tak samo dzieci, jak i starszych (Toffler, 1998, s. 62). Ciągłe przetasowania - dokonujące się, szczególnie pod wpływem reklamy, ale niekontrolowane całkowicie przez nią, akcentuje Alvin Toffler, nadają codziennemu życiu jednostek oszałamiający dynamizm. Wzmagają one jeszcze bardziej poczucie szybkości, zamieszania i nietrwałości społeczeństwa (Toffler, 1998, s. 77). Wśród wielu istotnych czynników stymulujących szybkość i przejściowość produktów, na które obszernie i precyzyjnie zwraca uwagę Toffler, ważna jest także machina mody, która obecnie jak dobrze naoliwiona maszyna tworzenia i rozpowszechniania mód jest ugruntowaną częścią nowoczesnej gospodarki. Stosowane w niej metody będą w coraz większym stopniu przejmowane przez innych, którzy uznają konieczność stałego skracania cyklu życiowego produktu. Granica między „krzykiem mody” a zwyczajnym produktem będzie zamazywać się coraz bardziej. Szybko wkraczamy w epokę krótkotrwałych produktów wykonywanych krótkotrwałymi metodami w celu zaspokojenia krótkotrwałych potrzeb, co znamiennie akcentuje autor. W ten sposób przepływ rzeczy przez nasze życie, od najmłodszych lat, staje się jeszcze bardziej szalony. Stoimy przed problemem rosnącego napływu przedmiotów przeznaczonych do wyrzucania po jednorazowym użyciu, nietrwałej architektury, wynajmowanych dóbr i artykułów pierwszej potrzeby przeznaczonych na niemal natychmiastową śmierć. Silne naciski płynące z tych wszystkich kierunków prowadzą do tego samego celu - nieuniknionej przemijalności stosunków między ludźmi a rzeczami (Toffler, 1998, s. 80). Toffler w swoich badaniach podejmuje jeszcze wiele kwestii związanych z szokiem przyszłości, które w niezwykle wnikliwy sposób diagnozuje, analizuje i futuryzuje, akcentując nieustannie szok, który ostatecznie zmienia człowieka i społeczeństwo ze stabilnego i trwałego w niestabilne i nietrwałe, co niestety dotyka także najmłodszych. 


\section{WZMACNIANIE CZŁOWIEKA, DZIECKA-OSOBY I GŁĘBOKICH, TRWAŁYCH INTERPERSONALNYCH RELACJI}

W kontekście potężnego oddziaływania technokracji i osaczania światem materii, na co zwróciłem uwagę powyżej, Maciej Tanaś zachęca, aby sięgnąć do alfabetu mediów, zrozumieć ich język, rolę, funkcję i wielorakie uzależnienia oraz rehabilitując rolę wychowawcy i nauczyciela - podjąć żmudny trud prowadzenia za rękę ucznia-wędrowca, człowieka w medialnym czy wirtualnym świecie, tak, aby skały nie raniły mu stóp, a może jeszcze bardziej umysłu i serca (Tanaś, 2007, s. 199).

Pomocna może być intensyfikacja i profesjonalizacja komunikacji interpersonalnej bezpośredniej, gdzie personalizm systemowy jest bazą koncepcyjną, akcentującą wartość człowieka-osoby, także dziecka, natomiast komunikacja interpersonalna bezpośrednia to dynamika interakcji, empatii i wzajemnego zrozumienia oraz permanentnego rozbudzania wartości w wychowanku i wychowawcy, dawania sobie wsparcia, o czym w dalszej części artykułu.

Klasyczne stwierdzenie w pedagogice i antropologii brzmi, że koncepcja wychowania, komunikowania zależy przede wszystkim od koncepcji człowieka (zob. Olbrycht, 2019). Błędy antropologiczne zawsze owocują problemami w komunikacji i w wychowaniu. Ostatnimi błędami, które szczególnie doprowadzają do niszczenia człowieka, to błąd materialistyczny, przez który sprowadza się człowieka do jednego wymiaru - materialnego; ale także błąd liberalny - gdzie akcentuje się tylko jeden wymiar człowieka - wolność, także w formie skrajnej, nie akcentując konieczności kompromisów w relacjach interpersonalnych, które są drogą do budowania wspólnoty. Błąd materialistyczny pojawia się dziś właśnie w formie reizacji osoby, o czym postarałem się napisać wcześniej; błąd liberalny zaś przyczynił się do skrajnego indywidualizmu, który bardzo wnikliwie analizuje Francis Fukuyama (zob. Fukuyama, 2000). Skrajny liberalizm obecnie powoduje także nadmiar możliwości od wczesnego dzieciństwa, w czym może pogubić się człowiek, zarówno młodszy, jak i starszy, na co także zwrócono uwagę wcześniej.

Personalizm systemowy to moim zdaniem antropomocna, integralna, adekwatna i stymulująca koncepcja człowieka, która może dziś pomóc wyjść obronną ręką z potężnej presji mediatyzacji i reizacji współczesnego człowieka.

Wśród wielu koncepcji personalistycznych jedną z najlepszych jest koncepcja profesora Wincentego Granata, którą postaram się zaadaptować na potrzeby niniejszej pracy, korzystając z analiz profesora Czesława Bartnika. Dla Wincentego Granata integralna osoba ludzka to jednostkowy, substancjalny i całkowity podmiot cielesno-duchowy, zdolny działać w sposób rozumny, dobrowolny i społeczny w celu harmonijnego ubogacenia siebie i ludzkości w zakresie całego bytu, całej rzeczywistości (Bartnik, 2000, s. 155). Powyższe określenie daje szczególną moc, 
jaką jest integralność w kontekście trendów fragmentarystycznych, następnie całkowitość, spójność podmiotu cielesno-duchowego wobec różnych tendencji dualistycznych i obniżających wartość cielesności lub duchowości, a także konsekwentnie rozumność wobec irracjonalności i wirtualizacji, oraz dobrowolność wobec różnych jawnych lub jeszcze częściej utajonych przymusów, konsekwentnie zaś szczególnie uspołecznienie i prospołeczność wobec potężnej skali indywidualizmu, egoizmu i narcyzmu w przestrzeni realnej i wirtualnej.

Analizując poszczególne komponenty człowieka-osoby w koncepcji profesora Granata, warto zaakcentować ich głębię, szczególnie to, że są one równie ważne i cenne w życiu oraz rozwoju dziecka:

- integralna osoba ludzka - integralna oznacza całość elementów, łącznie ze strukturą duchową, cielesną, psychiczną, biologiczną, relacją do społeczności i dalej wszystko co ludzkie, aby - kontynuując myśl profesora - nic co ludzkie nie zostało zaniedbane, ani też nieproporcjonalnie przeakcentowane;

- podmiot cielesno-duchowy - osoba jest podmiotem, a więc pewną istotną wewnętrznością i niepodzielnością, jest bytowaniem „w siebie”; podmiot jest szczególny ze względu na złożenie w sobie zintegrowanych, a zarazem przeciwstawnych pierwiastków: cielesnego i duchowego, które choć są pełne wzajemnych napięć, winny drogą pracy nad sobą ulegać integracji;

- podmiot całkowity - obejmuje wszystkie warstwy bytu ludzkiego: całą naturę, świadomość, podświadomość, nadświadomość i w ogóle biopsychiczną całość; osoba nie jest tylko jakimś elementem i nie ogranicza się do samej sfery duchowej człowieka; personalizm uświadamia także ogromną wartość sfery cielesnej w klimacie uprzedmiotowienia tej sfery albo jej nadmiernej gloryfikacji;

- podmiot jednostkowy - podmiot osobowy to byt konkretny, jeden i niepowtarzalny: osadzony w czasie i przestrzeni, niepowtarzalny, o sobie tylko właściwych cechach i przymiotach; im głębsza osobowość, tym wyższa indywidualność i wyrazistsza jednostkowość oraz radykalniejsza odrębność; osoba jest jedyna, nieprzemienna, niezmienna, niepowielalna, niepodzielna; także dziecko to niepowtarzalna osoba;

- podmiot substancjalny - jest to "Ja” i zarazem substancja bytowa, subsystentna, samoistna, nie stanowi części żadnego podmiotu, lecz istnieje w sobie (in se) i przez siebie (per se); istnieje przedziwna jedność owego „Ja” i substancji samoistnej, ale substancja ma pierwszeństwo ontyczne przed świadomością; dlatego tak wielka jest wartość człowieka jako człowieka, także a może szczególnie dziecka;

- jednostka ludzka jest zdolna do działania w sposób rozumny, dobrowolny i społeczny; myśl wyodrębnia człowieka ze świata przyrody; myśl to two- 
rzenie pojęć, wnioskowanie, sądzenie, intuicja duchowa i refleksja; ponadto podmiot ludzki jest wolny, a więc samopowtarzalny, odpowiedzialny, obdarzony możliwością wyboru, podejmujący decyzję;

- podmiot ludzki jako osoba jest odniesiony do społeczności ludzkiej przez dobro wspólne;

- osoba ludzka działa w celu ustawicznego bogacenia siebie w zakresie całego bytu; człowiek jako osoba jest istotą dynamiczną, stającą się, zmieniającą, rozwijającą; w tym tworzy wartości, realizuje siebie w działaniu, rozwija swoje człowieczeństwo; osoba kreuje sens swego istnienia (za: Bartnik, 2000, s. 155-156).

\section{PARADYGMAT KOMUNIKACJI INTERPERSONALNEJ}

Personalizm systemowy, gdzie w centrum jest człowiek-osoba i społeczeństwo jako wspólnota osób, realizuje się, doskonali i spełnia w sposób szczególny poprzez komunikację interpersonalną, bezpośrednią, dlatego warto poświęcić uwagę dynamicznemu paradygmatowi komunikacji interpersonalnej. Paradygmat to bardzo dynamiczna konstrukcja, posiadająca jak dogmaty swoje stałe i trwałe elementy, ale równocześnie, ponieważ dotyczy człowieka i społeczeństwa, ma swoją specyfikę adekwatną do okresów rozwojowych, specyfiki człowieka, rodzica, dziecka, nauczyciela, ucznia i grupy, a także kontekstu społecznego oraz pewnej dynamiki oraz zmienności w czasie i miejscu. Dlatego winna zawierać następujące elementy w perspektywie relacji rodzic - dziecko, nauczyciel - uczeń, które w mojej opinii są jednymi z najistotniejszych:

- komunikowanie interpersonalne wymaga bezpośrednich spotkań jego uczestników face to face - dopuszcza się sposoby komunikowania się polegające na korzystaniu z tzw. pośredników, a więc komunikacji zapośredniczonej medialnie, ale jednak powinna być dominacja pierwszej, o co tak mocno dopomina się dziś dziecko, w sposób mniej czy bardziej świadomy;

- komunikowanie interpersonalne występuje między OSOBAMI, mniej między rolami, choć role spełniają także bardzo ważną funkcję i nie powinno się $\mathrm{z}$ nich rezygnować (rola rodzica, nauczyciela), najmniej między maskami, czy stereotypami - „może zaistnieć tylko wtedy, gdy rozpoznajemy w sobie OSOBY, różniące się od siebie OSOBY...” (zob. Steward, 2002);

- dwukierunkowość - komunikowanie interpersonalne stanowi ZAWSZE zjawisko dwukierunkowe, interaktywne, przepływ wartości między osobami; dziecko też potrafi bardzo wiele nauczyć, a najczęściej bardzo mocno uskrzydlić, zmotywować; 
- nadawanie znaczeń - oznacza to, że możemy dokładnie i jednoznacznie, wielowymiarowo (zawsze i wszędzie), a także wielowarstwowo (cały integralny człowiek) ustalić treść jakiegokolwiek przekazu, a także go zweryfikować, ciągle doskonaląc nasze relacje w procesie wzajemnego przebaczania;

- intencja - jest związana z osobistym pragnieniem komunikowania i budowania innych i siebie na wszystkich płaszczyznach i w każdych okolicznościach („ten człowiek mnie zbudował”);

- internalizacja (uwewnętrznianie) wartości w osobie, w osobie rodzica i dziecka, spójność wartości wyznawanych z komunikowanymi, a także przepływ wartości między osobami;

- maieutyzacja (rozbudzanie) wartości w wychowanku i w sobie;

- proces - komunikowanie interpersonalne wychowujące, jest bardziej nieprzerwanym długofalowym procesem niż pojedynczym wydarzeniem, często trwa bardzo długo, a nawet przez całe życie;

- czas - należy brać pod uwagę całą historię wzajemnych konkretnych ludzkich relacji, przeszłość naszego dziecka dla teraźniejszości, a także dla jeszcze lepszej przyszłości (zob. Morreale, Spitzberg, Barge, 2008).

Według mnie niemożliwe wydaje się wyczerpanie w tym miejscu zagadnienia całości struktury paradygmatu komunikacji interpersonalnej. Starałem się przywołać kilka najważniejszych elementów, które nieustannie ubogacane, wzmacniane i stymulowane mogą być drogą do lepszego człowieczeństwa i społeczeństwa, szczególnie w relacjach rodzic - dziecko, nauczyciel - uczeń, gdzie każdy może i powinien wypracować sobie swój własny paradygmat.

Moim zdaniem szczególną rolę w budowaniu trwałych i mocnych więzi międzyludzkich, szczególnie w okresie wczesnym, ale także w każdym okresie w życiu, odgrywają emocje, bardzo mocno dziś bombardowane przez przekazy medialne, dlatego pragnę na koniec bardzo gorąco zaprosić do troski o dojrzałość emocjonalną i o dobre, zdrowe emocje. Warto przypomnieć, że dojrzałość emocjonalna, według profesor Ireny Obuchowskiej, polega na:

- zdolności uniezależniania się od otoczenia (aprobaty, dezaprobaty), zdolności bycia sobą; szczególnie uniezależniania się od wirtualnych zależności i presji;

- zdolności kontrolowania, uzewnętrzniania swoich emocji stosownie do wymogów społecznych - proces uspołecznienia nasycony wartościami i proegzystencją;

- zdolności sterowania swoimi emocjami poprzez standardy wewnętrzne normy sumienia;

- zdolności przechodzenia od „ja” do „my”, od egocentryzmu i narcyzmu do altruizmu (za: Szewczyk, 1998, s. 120). 


\section{PODSUMOWANIE}

Znamiennie kończą swoją książkę o iMózgu Gary Small i Gigi Vorgan, którzy mocno akcentują ogromną skalę zmian, a podtytuł mówi sam za siebie - Jak przetrwać technologiczna przemianę współczesnej umysłowości. W ostatnich zdaniach podkreślają, że zdając sobie sprawę z zagrożeń, takich jak uzależnienia high-tech i wielozadaniowość, musimy zadbać o zbliżenie mózgów Cyfrowych Imigrantów do Cyfrowych Tubylców, co powinno stać się naszym priorytetem. Gdy przerzucimy mosty, nauczymy się komunikować i pracować ze sobą w każdym wieku, będziemy gotowi na przyjęcie tego, co przyniesie przyszłość. Nie tylko przetrwamy ewolucję współczesnego mózgu, ale i dzięki niej rozkwitniemy (Small, Vorgan, 2011, s. 274). Stanie się to jednak tylko za pomocą komunikowania interpersonalnego bezpośredniego, nacechowanego mocno personalizmem i bogactwem świata wartości, a także dobrymi, zdrowymi emocjami, szczególnie w relacjach rodzic - dziecko, nauczyciel - uczeń, gdzie dokona się zbliżenie umysłów, ale także serc.

\section{LITERATURA}

Bartnik, C. (2000). Personalizm. Lublin: „O.K.” Tomasz Wiater.

Gergen, K. (2009). Nasycone Ja. Warszawa: PWN.

Melosik, Z. (2013). Kultura popularna i tożsamość młodzieży. Kraków: Impuls.

Morreale, S.P., Spitzberg, B.H., Barge, J.K. (2008). Komunikacja między ludźmi. Warszawa: PWN.

Olbrycht, K. (2019). Edukacja kulturalna jako edukacja do wzrastania w człowieczeństwie.

Katowice: Wyd. Uniwersytetu Śląskiego.

Patzlaff, R. (2008). Zastygłe spojrzenie. Kraków: Impuls.

Small, G., Vorgan, G. (2011). iMózg. Poznań: Vesper.

Spitzer, M. (2016). Cyberchoroby. Słupsk: Dobra Literatura.

Steward, J. (2002). (red.). Mosty zamiast murów. Warszawa: PWN.

Szewczyk, W. (1998). Rozumieć siebie i innych. Tarnów: Biblos.

Szmyd, J. (2015). Zagrożone człowieczeństwo. Katowice: Stowarzyszenie Thesaurus Silaesie - Skarb Śląski.

Tanaś, M. (2007). Wychowanie a media. W: B. Siemieniecki. Pedagogika medialna. Warszawa: PWN.

Tapscott, D. (2010). Cyfrowa dorosłość. Warszawa: Wydawnictwa Akademickie i Profesjonalne.

Toffler, A. (1998). Szok przyszłości. Poznań: Zysk i S-ka. 


\title{
PROMOTION AND INTENSIFICATION OF DIRECT INTERPERSONAL COMMUNICATION PARENT - CHILD, TEACHER - STUDENT IN THE WORLD \\ OF TECHNOCRACY AND BEING SURROUNDED BY MATERIAL CAPITAL
}

\begin{abstract}
Introduction: The realization of a human (Latin res - a thing), especially of a child, that is encircling the material world on a large scale, especially media gadgets, is currently one of the greatest psychological and pedagogical problems and one of the greatest challenges. The world of things is also a beautiful world, today also the world of multimedia, which help a lot in everyday life, especially in the context of a pandemic, but at the same time, all this requires great wisdom not to destroy the world of priceless interpersonal relationships - interpersonal, direct, face to face, closeness that are especially important and invaluable for the proper development of a child and every human being, always and everywhere. Purpose: The aim of this research is to draw attention to the above problem and to mobilize in particular to promote and strengthen super-important and absolutely necessary direct interpersonal relations, in which there is a serious deficit. In this regard, it seems that research is still necessary. Many teachers from my personal conversations and interviews confirm a huge deficit of knowledge about interpersonal communication among parents as well as the difficulty of assimilating it in everyday life, due to, among other things, the pace of life and the transfer of communication into media-mediated communication. The promotion and permanent training of interpersonal communication from an early age by parents and teachers with children and students, as well as with each other, is a hope for saving the essence of humanity and society.
\end{abstract}

Keywords: child, interpersonal communication, material capital, parent, technocracy 